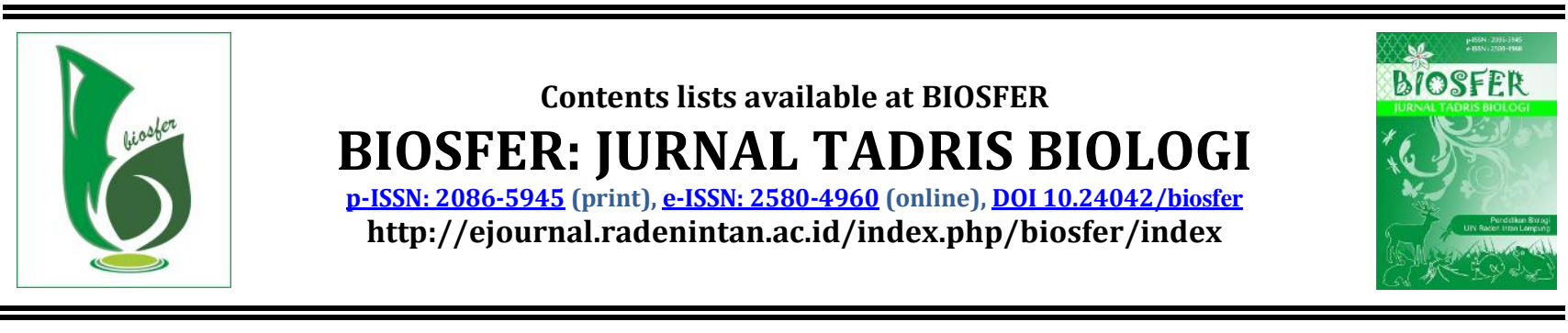

\title{
The Effect of GA3 and Salicylic Acid Combination on the Growth of Groundnut Sprout (Arachis Hypogaea L.) on Aluminum Stress
}

\author{
Noviani' ${ }^{1}$, Martha Lulus Lande ${ }^{2}$, Zulkifli ${ }^{3}$, Yulianty ${ }^{4}$ \\ 1,2, 3,4 Biologi Study Program, Mathematics Faculty of Lampung University, Indonesia.
}

\begin{tabular}{|c|c|}
\hline ARTICLE INFO & ABSTRACT \\
\hline $\begin{array}{l}\text { Article History } \\
\text { Received: } 16-01-2020 \\
\text { Accepted: } 02-08-2020 \\
\text { Published: } 31-12-2020\end{array}$ & $\begin{array}{l}\text { This study aimed to determine the influence of GA3 and salicylic } \\
\text { acid on the germination and growth of Kelinci variety groundnut } \\
\text { under aluminum stress. The research was conducted in the } \\
\text { Botanical Laboratory of the Faculty of Mathematics and Natural }\end{array}$ \\
\hline $\begin{array}{l}\text { Keywords: } \\
\text { Aluminum; } \\
\text { Salicylic Acid; } \\
\text { GA3; } \\
\text { Groundnuts. }\end{array}$ & $\begin{array}{l}\text { Sciences, University of Lampung. This research was conducted in a } \\
2 \times 3 \text { factorial experimental design. Factor A was AL }(\mathrm{OH}) 3 \text { with } \\
\text { two levels of concentration: } 0 \% \mathrm{~b} / \mathrm{v} \text { and } 5 \% \mathrm{~b} / \mathrm{v} \text {. Factor B was } \\
\text { Growth Stimulant Substance (ZPT) with three levels of } \\
\text { concentration: GA3 }(0.1 \% \mathrm{w} / \mathrm{v}) \text {, salicylic acid }(0.1 \% \mathrm{w} / \mathrm{v}) \text {, and GA3 } \\
\text { and salicylic acid. The Tukey test determined the Main Effect, and } \\
\text { the Simple Effect was determined with F-test at a significant level }\end{array}$ \\
\hline $\begin{array}{l}\text { *Correspondence Address: } \\
\text { nnoviani2812@gmail.com }\end{array}$ & $\begin{array}{l}\text { of } 5 \% \text {. It can be concluded that the mixture of GA3 solution and US } \\
\text { solution was more effective than a single solution of GA3 or US. }\end{array}$ \\
\hline
\end{tabular}

Efek GA3 dan Kombinasi Asam Salisilat pada Pertumbuhan Kecambah Groundnut (Arachis Hypogaea L.) pada Stres Aluminium.

\begin{abstract}
Abstrak: Penelitian ini bertujuan untuk mengetahui pengaruh GA3 dan asam salisilat terhadap perkecambahan dan pertumbuhan kacang tanah varietas kelinci dibawah cekaman aluminium. Penelitian dilaksanakan di Laboratorium Botani Fakultas Matematika dan Ilmu Pengetahuan Alam Universitas Lampung. Penelitian ini dilaksanakan dalam percobaan faktorial $2 \times 3$. Faktor A adalah AL(OH)3 dengan dua taraf konsentrasi : 0\% b/v dan 5\% b/v. Faktor B adalah Zat Perangsang Tumbuh (ZPT) dengan tiga taraf : GA3 $(0,1 \% \mathrm{~b} / \mathrm{v})$, asam salisilat $(0,1 \% \mathrm{~b} / \mathrm{v})$ dan GA3 + asam salisilat. Main effect ditentukan dengan uji Tukey dan simple effect dengan uji $\mathrm{F}$ masing-masing pada taraf nyata $5 \%$. Dari hasil penelitian disimpulkan bahwa campuran larutan GA3 dan larutan AS lebih efektif dari pada larutan tunggal GA3 atau larutan AS dalam mengatasi efek toksik aluminium terhadap perkecambahan dan pertumbuhan kecambah kacang tanah varietas kelinci.
\end{abstract}




\section{INTRODUCTION}

Groundnut is a protein source in the Indonesian diet with a high economic value in agribusiness commodities (Rahayu et al., 2020; SAIRDAMA, 2017; Sembiring et al., 2014). The yearly needs for groundnuts are increasing along with population and nutritional needs (Gulo et al., 2020; Hama, 2018; Rozak, 2020), food diversification, and the feed and food industry in Indonesia (Ariani et al., 2013; Santoso, 2017). However, Indonesian groundnut production has not been sufficient because it requires imports from abroad (Puspita \& Tambunan, 2018; Siregar et al., 2017; Ulhair et al., 2018). Therefore, the government strives to increase production by expanding the planting area and using appropriate fertilizers (Bimasri \& Murniati, 2017; Sembiring et al., 2014).

In Indonesia, people consider groundnuts as an industrial food ingredient (Abdullah et al., 2014; Mutia \& Saleh, 2016). The groundnut is usually planted in rice fields or moor singly or in multiple ways in an intercropping system(Rahmi, 2017; Simbolon, 2017; Wahyusi et al., 2012). As a food ingredient, groundnut seeds contain lots of fat and protein (Kurniawan \& Purnamawati, 2017; Santosa, 2010; Surya et al., 2013). Groundnut production in Indonesia ranks second after soybeans (Simamora et al., 2013; Sugari \& Islami, 2019). Groundnuts have a major role in meeting the needs of legumes (Mayura \& Idris, 2019). Groundnuts also contains $25-30 \%$ protein, $40-50 \%$ fat, $12 \%$ carbohydrates, and vitamin B1. Those nutritional contents place groundnuts' nutritional fulfillment second after soybean (Aslamiah \& Sularno, 2018). In the industrial sector, groundnuts are used to produced margarine, soap, cooking oil, and many others (Gusmiatun et al., 2020; Merta et al., 2018).

Production can be increased using superior varieties and improving technical cultures, such as plant care, proper fertilization, and drainage systems. (Primandari, 2019; Sembiring et al., 2014). One of the reasons for the decline in groundnut production is the gynophore's inability to enter the soil, which causes the gynophore to fail to form pods (Hadi, 2017). Salicylic acid is an important signal in plant resistance used to impact resistance to disease (Primandari, 2019; AR Putri, 2017). Plants' salicylic acid responses to pathogenic attacks as a form of defense (Afkar et al., 2019; AOT Putri et al., 2016). Salicylic acid is a hormone naturally produced by plants (Novita \& Siregar, 2015; Yulianti, 2012). Salicylic acid is a phenolic compound with a tolerance effect against abiotic stress (EFENDI, 2016).

Research on GA3 was previously done on maize and bean germination (Noviana \& Nurcahyani, 2019; Sriyanto et al., 2019), salicylic acid on sprouts growth (Andriani et al., 2015; Noviana \& Nurcahyani, 2019), maize and rice (Arachis Hypogaea L.), groundnuts variety with SP36 fertilizer and pore width on leaf stomata (Hayati et al., 2012; Taluta et al., 2017), and the role of phosphorus in aluminum stress (Lestari et al., 2017). This research aimed to determine the effect of GA3 and salicylic acid on germination and growth of Kelinci varieties of groundnuts under aluminum stress.

\section{METHOD}

This research was conducted at the Botanical Laboratory, Faculty of Mathematics and Natural Sciences, the University of Lampung, from November to December 2018. The equipment used in this study were plastic trays, plastic cups, filter paper, labels, tissues, rubber bands, plastic, beaker glass, Erlenmeyer, measuring cup, volume pipette, drop pipette, test tube, mortar, crucible rack, 
digital scale, centrifuge, oven, UV spectrophotometry, knife, scissors, and ruler. The materials used in this study were groundnut seeds obtained from the Lampung Province Seed Center, Al (OH) 3, gibberellin hormone (GA3), salicylic acid, alcohol, and distilled water. This research was conducted using a $2 \times 3$ factorial experimental design. Factor A was $\mathrm{Al}(\mathrm{OH})$ 3 with the concentration levels of $0 \% \mathrm{w} / \mathrm{v}$ and $0.5 \% \mathrm{w} / \mathrm{v}$.

There were 48 normally germinated seeds were selected. The container used for the sprouts was a plastic cup. A total of 24 plastic cups were washed and wiped dry. They were then labeled with the treatment and repeat combination notation. Furthermore, the plastic cups were coated with tissue and filter paper moistened with $0.1 \mathrm{ml}$ of GA3, $5 \mathrm{ml}$ of salicylic acid, a mixture of $0.1 \mathrm{ml}$ of GA3, and a mixture of $0.1 \mathrm{ml}$ of salicylic acid. Each plastic cup contained two sprouts. The germination variable was observed for 7 days after the treatment.

\section{RESULTS AND DISCUSSION}

Each treatment combination was repeated four times so that the number of experimental units was 24. This study's variables were germination power, shoot length, fresh weight, dry weight, relative moisture content, and chlorophyll a, b, and total. This study's parameters were all mean $(\mu)$ values of all the growth variables of groundnut sprouts.

The $\mathrm{Al}(\mathrm{OH}) 3$ solution was made from 0.5 grams of $\mathrm{Al}(\mathrm{OH}) 3$ powder dissolved in $100 \mathrm{ml}$ of distilled water to obtain a concentration of $0.5 \% \mathrm{w} / \mathrm{v}$. Then, the GA3 solution was made from 0.1 gram of GA3 powder dissolved in $100 \mathrm{ml}$ of distilled water to obtain a concentration of $0.1 \% \mathrm{w} / \mathrm{v}$. Likewise, the salicylic acid solution was made from 0.1 gram of salicylic acid powder dissolved in $100 \mathrm{ml}$ of distilled water to obtain a concentration of $0.1 \% \mathrm{w} / \mathrm{v}$. The seeds were selected by soaking them in distilled water for 10 minutes. The floating seeds and wastes were removed, while the sinking seeds were taken to be germinated.

The selected seeds were then soaked in three levels, namely, GA3, Salicylic Acid, and mixtures of GA3 + Salicylic Acid. Also, there were three levels of concentration of Al $(\mathrm{OH}) 3$, namely $\mathrm{Al}(\mathrm{OH}) 35 \% \mathrm{w} / \mathrm{v}+\mathrm{GA} 3$ , Al $(\mathrm{OH}) 35 \% \mathrm{w} / \mathrm{v}+$ Salicylic Acid, and $\mathrm{Al}$ $(\mathrm{OH}) 35 \% \mathrm{w} / \mathrm{v}+\mathrm{GA} 3+$ Salicylic Acid for 24 hours. The soaked groundnut seeds were spread out into six plastics covered with tissue paper and moistened with distilled water for germination. There were 600 deeds used to be placed in trays containing 100 seeds each. The effect of salicylic acid, GA3, and the combination of salicylic acid and GA3 is shown in Figure 1. 


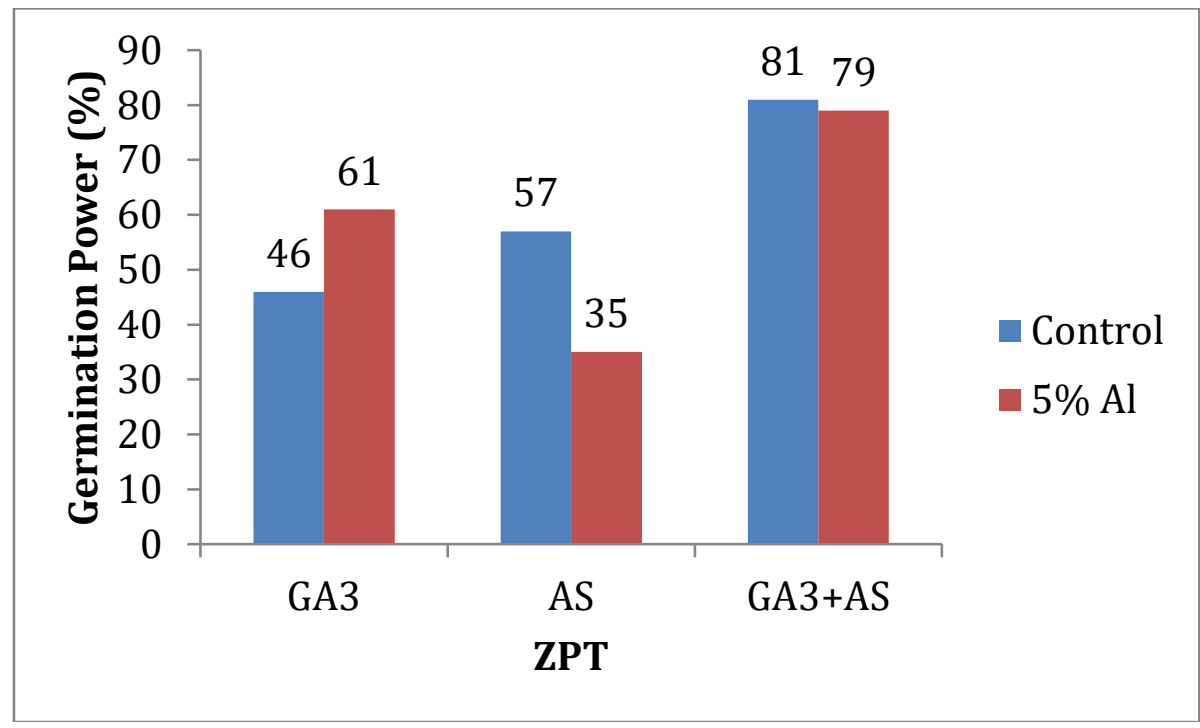

Figure 1. The Kelinci Variety Groundnut Sprouts At Various Concentrations of Salicylic Acid, GA3, and Salicylic Acid + GA3.

Aluminum toxicity (Al-toxicity) is one of the main factors limiting plant growth and development in many acid soils. The plasma membrane of root cells, especially the root apex, appears to be the main target of Al-toxicity. However, the strong interaction of $\mathrm{Al} 3+$, the main toxic form of $\mathrm{Al}$, with the oxygen donor ligands (proteins, nucleic acids, and polysaccharides) inhibits cell extension, cell division, and transport (Koentjoro \& Biotech, 2020).

The results of this study indicated that under normal growth conditions, GA3 + SA was more effective in encouraging seed germination seeds compared to salicylic acid and GA3. Likewise, SA was more effective than GA3 in encouraging the seed germination. GA3 + AS was more effective than SA and GA3 in encouraging the seed germination. GA3 was more effective than the SA in encouraging the seed germination (Sofiana \& Syaban, 2017). The germination success depends on two important physiological processes: the absorption of water by the seeds (imbibition) and the hydrolysis of starch to glucose as the main substrate in the respiration process. The $\alpha$ amylase enzyme catalyzes the hydrolysis of starch, while glucose is the main energy source for the germination process.

The simple effect analysis showed that at the GA3 level, $\mathrm{Al}(\mathrm{OH}) 3$ treatment decreased the average shoot length. In salicylic acid treatment, there was no significant shoot length difference between the control and $\mathrm{Al}(\mathrm{OH}) 3$. Likewise, at the level of GA3 + AS, there was no significant difference in the mean shoot length between control and $\mathrm{Al}(\mathrm{OH}) 3$.

Table 1. Simple Effect Analysis of Al $(\mathrm{OH}) 3$ at each level of ZPT on Shoot Lenght of Kelinci Variety Groundnut.

\begin{tabular}{ccccc}
\hline & \multicolumn{4}{c}{ ZPT } \\
\cline { 2 - 5 } Al (OH) 3 & Level & GA3 & US & GA3 + US \\
\cline { 2 - 5 } & Control & $4.25 a \pm 0.57$ & $4.88 a \pm 0.54$ & $4.075 a \pm 0.22$ \\
& $0.5 \%$ & $2.75 a \pm 0.32$ & $4.23 a \pm 0.144$ & $4.80 a \pm 0.43$ \\
\hline
\end{tabular}




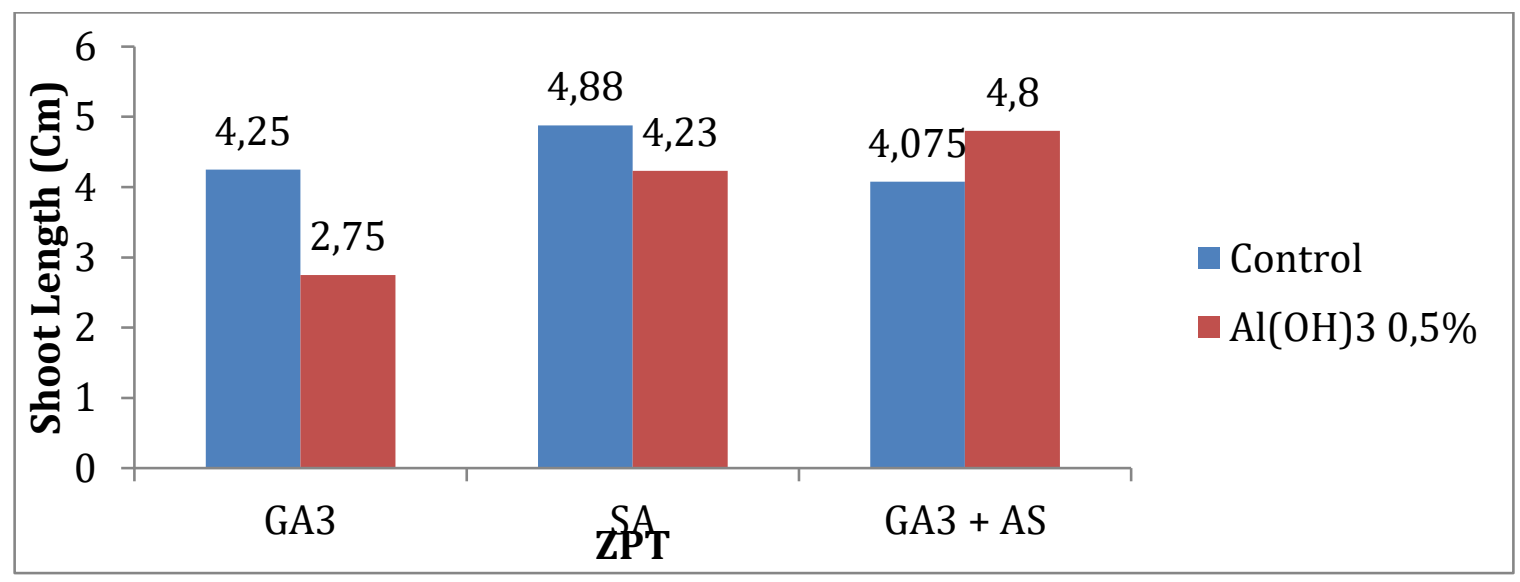

Figure 2. Simple Effect Analysis of $\mathrm{Al}(\mathrm{OH}) 3$ at each level of ZPT on Shoot Length of Kelinci Variety Groundnut.

The effect of salicylic acid, GA3, and the combination of salicylic acid and GA3 on the shoot length of Kelinci variety groundnut under aluminum hydroxide stress is shown in Figure 2. The Levene test at a significant value of $5 \%$ found that the population variety was homogeneous (attachment $1 \mathrm{p}>0.05$ ). The results showed that aluminum had no significant effect on shoot length, while ZPT significantly affected shoot length. The interaction between aluminum and ZPT had a significant effect on shoot length.

Table 2. Simple Effect Analysis of ZPT at Each Level of Al (OH) 3 on Shoot Length of Groundnut.

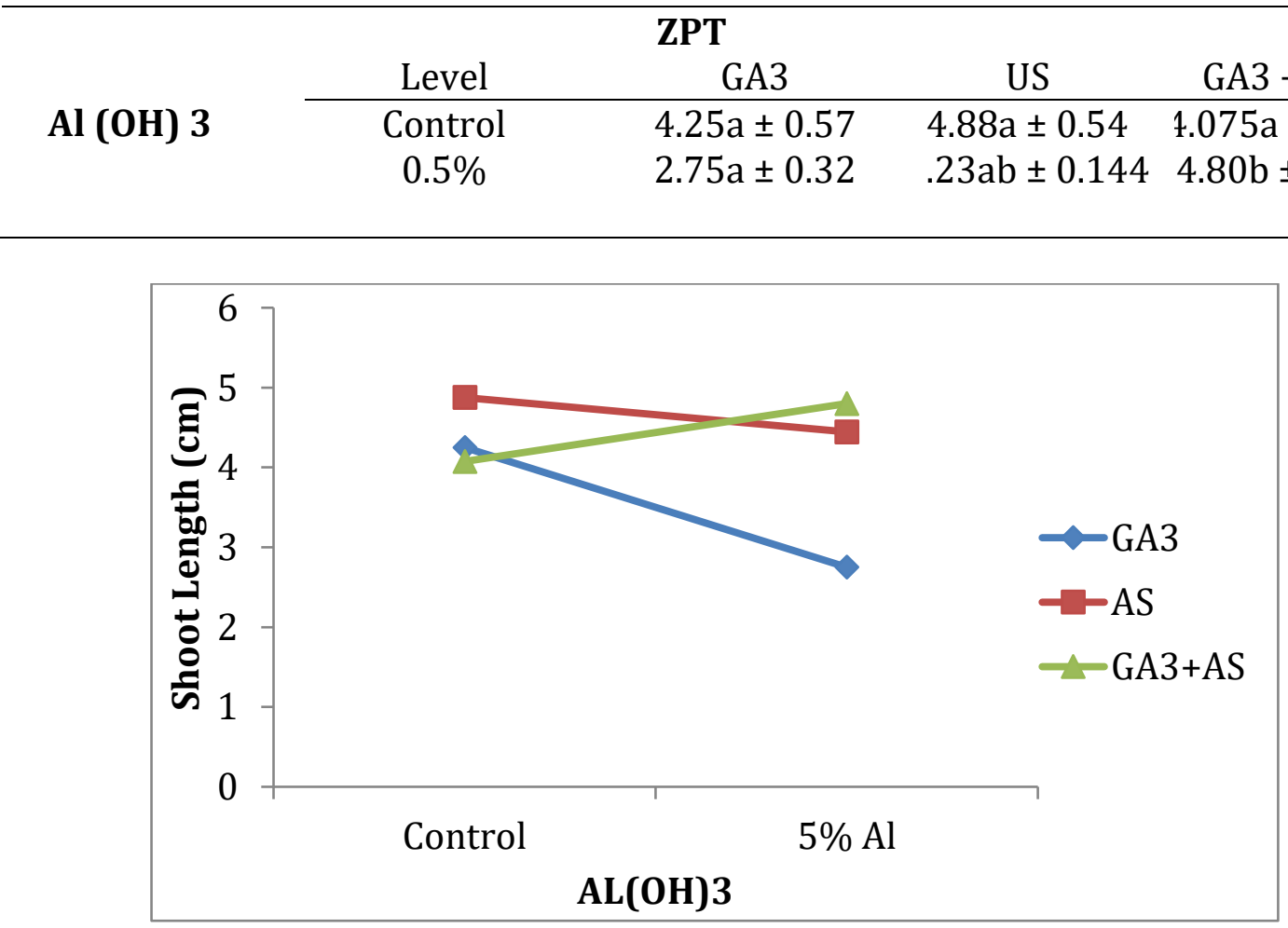

Figure 3. The Interaction Curve between ZPT and AL (OH) 3 on Shoot Length. 
Based on the interaction between $\mathrm{Al}$ $(\mathrm{OH}) 3$ and GA3, salicylic acid tended to reduce the average length of groundnut shoots. In contrast, the interaction between $\mathrm{Al}(\mathrm{OH}) 3$ tended to increase the shoot length. The effect of salicylic acid, GA3, and the combination of salicylic acid and GA3 on the fresh weight of Kelinci variety groundnuts under aluminum hydroxide stress is shown in Figure 4.

Table 3. Simple Effect Analysis of ZPT at Each Level of Al (OH) 3 on Fresh Weight of Groundnut Sprouts.

\begin{tabular}{ccccc}
\hline & ZPT & & \\
\hline Al (OH) 3 & Level & GA3 & US & GA3 + US \\
& Control & 0.815 & 1,198 & 0.895 \\
& $\mathrm{Al} \mathrm{(OH)} \mathrm{30.5 \%}$ & 0.864 & 1,728 & 0.955 \\
\hline Marginal mean & $0.839 \mathrm{a}$ & $1,463 \mathrm{~b}$ & $0.925 \mathrm{ac}$ \\
\hline
\end{tabular}

The Levene test at a $5 \%$ significant level showed that ZPT had a significant effect on sprouts' fresh weight. However,
$\mathrm{Al}(\mathrm{OH}) 3$ and its interaction with ZPT had no significant effect on sprouts' fresh weight.

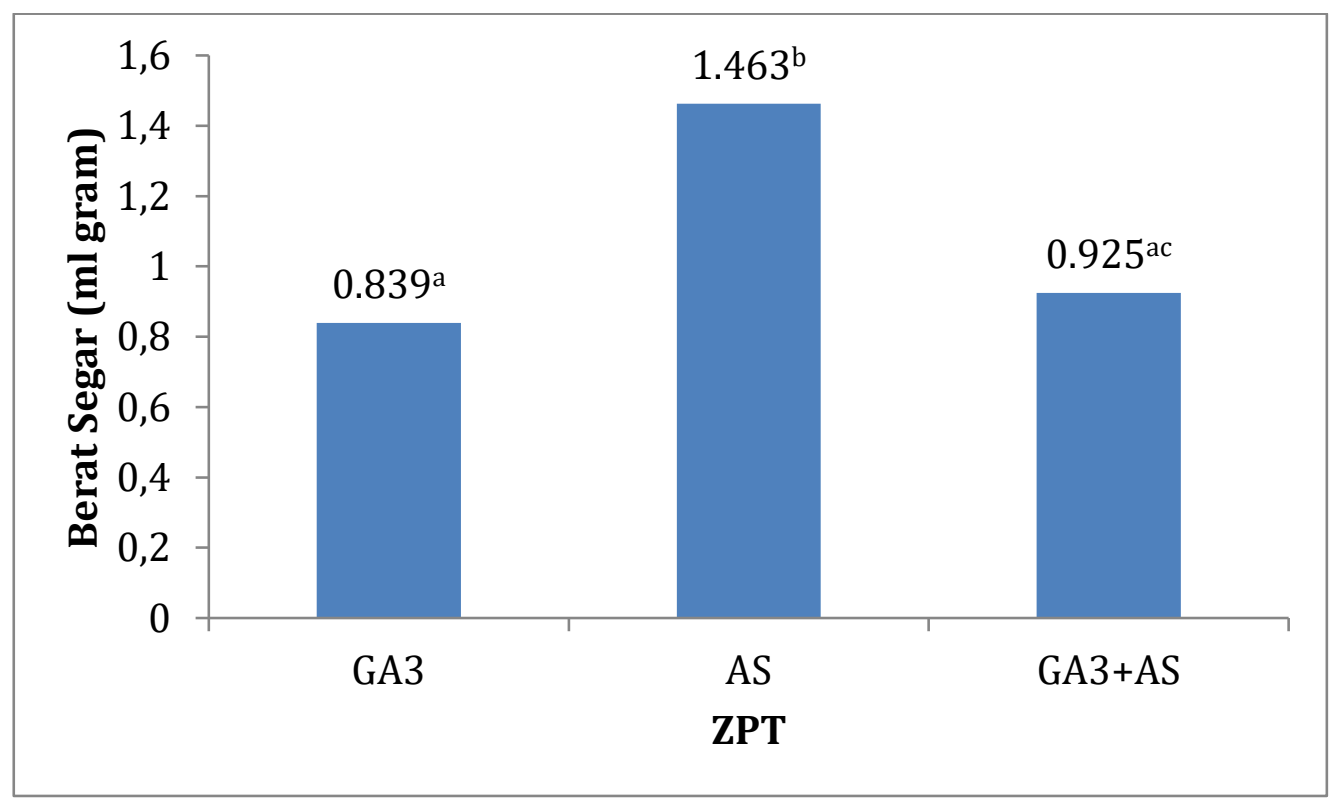

Figure 4. Main Effect Analysis of ZPT on Fresh Weight of Kelinci varieties Groundnut Sprouts

The main effect analysis showed that groundnut sprouts' response to GA3, salicylic acid, and GA3 + salicylic acid was relatively different. Salicylic acid had a higher stimulating effect than GA3 and GA3 + salicylic acid. Fresh weight is determined by the dry weight and relative moisture content of the sprouts. The water absorption rate by the roots and the rate of transpiration by the leaves determine the fresh weight of sprouts (Istiqhomah et al., 2019; Nio \& Torey, 2013; Prasetya et al., 2019). The allocation of food reserves from seeds or endosperm determines the dry weight of the plant. The results showed that the effect of ZPT did not depend on growing conditions. The fresh weight of sprouts did not differ relative to normal 
growth and aluminum stress conditions. SA was relatively better at stimulating water uptake by roots than GA3 and GA3 + SA (Kartawijaya, 2014).
The effect of ZPT and its interaction with $\mathrm{Al}(\mathrm{OH}) \quad 3$ on Kelinci variety groundnut sprouts' dry weight is shown in Table 4 .

Table 4. The Average Dry Weight of Kelinci Variety Groundnut Sprouts

\begin{tabular}{ccccc}
\hline & \multicolumn{3}{c}{ ZPT } & \\
\hline Al (OH) 3 & Level & GA3 & US & GA3 + US \\
& Control & $0.251 \pm 0.055$ & $0.286 \pm 0.020$ & $0.260 \pm 0.025$ \\
& Al (OH) 3 $0.5 \%$ & $0.328 \pm 0.065$ & $0.371 \pm 0.067$ & $0.294 \pm 0.048$ \\
\hline
\end{tabular}

The Levene test at the $5 \%$ significant level showed that the population variety was homogeneous. Uniform analysis at the $5 \%$ significant level showed that ZPT, Al $(\mathrm{OH}) 3$, and their interactions had no significant effect. The effect of ZPT and its interaction with $\mathrm{Al}(\mathrm{OH}) 3$ on Kelinci variety groundnut sprouts' relative moisture content is shown in Table 5.

Table 5. The Average Relative Moisture Content of Kelinci Variety Groundnut Sprouts

\begin{tabular}{ccccc}
\hline \multicolumn{5}{c}{ ZPT } \\
\hline Al (OH) 3 & Level & GA3 & US & GA3 + US \\
& Control & $70.0 \pm 5.5$ & $73.8 \pm 5.1$ & $70.7 \pm 3.1$ \\
& $\mathrm{Al}(\mathrm{OH}) 30.5 \%$ & $63.0 \pm 4.0$ & $77.2 \pm 5.7$ & $69.2 \pm 3.7$ \\
\hline
\end{tabular}

The Levene test at the $5 \%$ significant level showed that the population variance was homogeneous. Uniform analysis at the $5 \%$ significant level showed that ZPT, Al $(\mathrm{OH}) 3$, and their interactions had no significant effect. The aluminum stress condition did not affect the dry weight and relative moisture content of groundnut sprouts. Therefore, aluminum toxicity did not affect the allocation of food reserves. Likewise, the same phenomenon was found in the relative moisture content.

\section{CONCLUSION}

Based on the analysis, it can be concluded that a mixture of GA3 solution and SA solution was more effective than a single GA3 solution or SA solution in overcoming Al-toxicity on germination and growth of Kelinci variety groundnut sprouts. It is suggested to research the effects of a mixture of GA3 and SA solutions on germination and other sprouts' growth.

\section{REFERENCES}

Abdullah, AB, Rusli, A., \& Badron, R. (2014). The improvement of the Langkose Nuts Production Process in Home Industries in Pinrang. Ngayah: Science and Technology Application Magazine, 5 (1).

Afkar, R., Sitepu, FET, \& Hasanah, Y. (2019). Growth and Production Response of Wilis (Glycine Max (L.) Merril.) Soybean Variety to Salicylic Acid and Chitosan Applications. Journal of Tropical Agriculture, 6 (1), 153159. 
Andriani, A., Zulkifli, Z., \& Handayani, TT (2015). Effect of Salicylic Acid on the Growth of Upland Rice Sprouts of Situ Bagendit Varieties. Proceedings of the National Seminar on Agricultural Technology Development.

Ariani, M., Hermanto, GS, Hardono, S., \& Ts, W. (2013). Study of Local Food Diversification Development Strategies. Report on the Study of Actual Issues of Agricultural Development Policy. Center for Socio-Economic and Agricultural Policy. Bogor.

Aslamiah, ID, \& Sularno, S. (2018). Groundnut Growth and Production's response to Increasing Concentration of Organic Fertilizers and Reducing Doses of Inorganic Fertilizers. Proceedings of Semnastan, 115-126.

Bimasri, J., \& Murniati, N. (2017). Exploration of the Benefits of Eggshell Waste to Increase Soybean (Glycine Max L. Merril) Production in Ultisol Soil. Chlorophyll: Journal of Agricultural Sciences Research, 12 (1), 52-57.

Efendi, MY (2016). Effect of Salicylic Acid Concentration on Growth of Koro Sword Nuts (Canavalia Ensiformis L) in Ultisol Soil. Student Scientific Journal of the Faculty of Agriculture, $3(2)$.

Gulo, YS, Marpaung, RG, \& Manurung, AI (2020). The Effect of Npk Mutiara Fertilizer and the Number of Seeds per Planting Hole on the Growth and Production of Groundnuts of Tasia I Variety (Arachis Hypogaea L.).
Journal of Darma Agung, 28 (3), 525-548.

Gusmiatun, G., Palmasari, B., \& Riani, E. (2020). The Effect of Phosphate Fertilizer With Different Dosages And Frequency On The Growth And Production Of Groundnuts (Arachis Hypogaea L. Merr). Chlorophyll: Journal of Agricultural Sciences Research, 14 (2), 98-101.

Hadi, MA (2017). Effect of Giving Mushroom Baglog Waste Compost and Sheep Manure on Growth and Yield of Groundnut (Arachis Hypogaea L.) Varieties of Sheep. Uin Sunan Gunung Djati Bandung.

Pest, S. (2018). Utilization of Tofu Dregs Compost for Growth and Production of Groundnut (Arachis Hypogaea L.). Perbal: Journal of Sustainable Agriculture, 6 (3), 48-58.

Hayati, M., Marliah, A., \& Fajri, H. (2012). Effect of Varieties and Doses of Sp36 Fertilizer on Growth and Yield of Groundnut (Arachis Hypogaea L.). Agrista Journal, 16 (1), 7-13.

Istiqhomah, S., Mukaromah, AS, \& Rusmadi, R. (2019). Effect of MS0 Medium Density on In Vitro Germination of Corn Kernels (Zea Mays L., Var. "Local"). Al-Hayat: Journal Of Biology And Applied Biology, 2 (2), 68-75.

Kartawijaya, I. (2014). National Seminar Proceedings. Proceedings of the National Seminar on Indonesian Tropical Biodiversity and Ecology (Bioeti), Andalas University, 1.

Koentjoro, MP, \& Biotech, M. (2020). Dynamics of Bacterial Cell Wall Structure. Jakad Media Publishing. 
Kurniawan, RM, \& Purnamawati, H. (2017). Response of Growth and Production of Groundnut (Arachis Hypogaea L.) to Groove Planting System and Type of Fertilizer. Agrohorti Bulletin, 5 (3), 342-350.

Lestari, T., Ardie, SW, \& Sopandie, D. (2017). The Role of Phosphorus in Increasing Sorghum Plant Tolerance to Aluminum Stress. Journal of Indonesian Agronomy (Indonesian Journal Of Agronomy), 45 (1), 4348.

Mayura, E., \& Idris, H. (2019). Utilization of Citronella Distillation Waste as Organic Fertilizer for Growth and Production of Groundnuts (Arachis Hypogea L.). Journal Of Applied Agricultural Science And Technology, 3 (1), 67-72.

Merta, JS, Asminar, A., \& Is, A. (2018). Dynamics of Groundnut Price Offer Response Between Bungur Market, Bungo Regency and Sarinah Market, Tebo Regency. Jas (Journal of Agri Sains), 2 (2).

Mutia, U., \& Saleh, C. (2016). Test of Lactic Acid Levels in Groundnut Cheese (Arachis Hypogaea L.) Based on Time Variations and Concentrations of Lactobacillus Bulgaricus and Streptococcus Lactis Bacteria. Mulawarman Journal of Chemistry, $10(2)$.

Nio, SA, \& Torey, P. (2013). Root Morphological Characters As WaterDeficit Indicators In Plants. Journal of Bios Logos, 3 (1).

Noviana, N., \& Nurcahyani, E. (2019). The Interaction Effect Between Peg, Ga3, And Salicylic Acid Treatment On The
Growth Of Sweet Corn (Zea Mays Saccharata Sturt) Cultivar Bimmo. Journal of Applied Agricultural Research, 10 (Xx), X - Xx.

Novita, A., \& Siregar, LA (2015). Response to Growth and Production of Rosella (Hibiscus Sabdariffa L.) in Saline Soil with Salicylic Acid and Giberellin (Ga3). Journal of Tropical Agriculture, 2 (3), 258-263.

Prasetya, Y., Astuti, YTM, \& Rahayu, E. (2019). Effect of Dormancy Breaking on Mucuna Bracteata Seeds. Agromast Journal, 1 (1).

Primandari, D. (2019). Effect of Combination of Ga3 and Salicylic Acid on Germination and Sprouts Growth in Groundnut (Arachis Hypogaea L.) Kelinci Cultivars Under Aluminum Stress.

Puspita, DE, \& Tambunan, SB (2018). Growth and Production Capacity of Four Groundnut (Arachis Hypogea L.) Varieties. Serambi Saintia: Journal of Science and Applications, 6 (2).

Putri, AOT, Hadisutrisno, B., \& Wibowo, A. (2016). Effect of Arbuscular Mycorrhizal Inoculation on Bibiit Growth and Clove Leaf Spot Disease Intensity. Journal of Forest Plant Breeding, 10 (2), 145-154.

Putri, AR (2017). Characterization of Cattleya (Cattleya Sp. Lindl.) Plantlets from Salicylic Acid Induction and Mycorrhizal Inoculation (Rhizoctonia Sp.) In Vitro.

Rahayu, A., Rahayu, MS, \& Manik, SE (2020). The Role of Various $N$ Sources on the Growth and 
Production of Various Groundnut Plant Varieties (Arachis Hypogaea L). Agriland Journal of Agricultural Sciences, 8 (1), 89-93.

Rahmi, N. (2017). The Relevance of the Curriculum and the Concrete Form of Arabic Learning Objectives. An Nabighoh: Journal of Arabic Language Education and Learning, 19 (1), 107-126.

Rozak, A. (2020). Effect of Manure Dose and Plant Distance on Growth and Production of Groundnut (Arachis Hypogaea L.) in Saline Fields. Biofarm: Agricultural Scientific Journal, 16 (2).

Sairdama, SS (2017). Analysis of Marketing Margin for Groundnut (Arachis Hypogaea L.) Commodity in Karadiri 1 Village, Wanggar District, Nabire Regency. Fapertanak Journal: Journal of Agriculture and Animal Husbandry, 2 (2), 48-587.

Santosa, BS (2010). Defatting Technology Innovation: Opportunities for Increasing Diversification of Groundnut Products in the Agricultural Industry. Agricultural Innovation Development, 3 (3), 199-211.

Santoso, AD (2017). Potential and Constraints in the Development of Sago as a Feed, Food, Energy and Environmental Sustainability in Indonesia. Journal of Environmental Engineering, 10 (2).

Sembiring, M., Sipayung, R., \& Sitepu, FE (2014). Growth and Production of Groundnuts with the Compost of Empty Palm Bunches at Different Stowing Frequencies. Journal of the
Agroecotechnology University of North Sumatra, 2 (2), 98329.

Simamora, L., Sebayang, T., \& Hutajulu, AT (2013). Analysis of Groundnut Farming Production and Income in North Tapanuli District (Case Study: Banuaji Iv Village, Adiankoting District). Journal of Agriculture And Agribusiness Socioeconomics, 2 (5), 15065.

Simbolon, FJ (2017). Analysis of Factors Affecting Groundnut Supply in North Sumatra. Methodagro, 3 (1), 37-44.

Siregar, SH, Mawarni, L., \& Irmansyah, T. (2017). Growth and Production of Groundnut (Arachis Hypogea L.) With Several Cultivation Systems And Microbial Associations: Growth And Yield of Groundnut (Arachis Hypogea L.) To Some Tillage And Addition of Microbe Association. Online Journal of Agroecotechnology, 5 (1), 202-207.

Sofiana, R., \& Syaban, RA (2017). Application of Biourine Fertilizer on Yield and Seed Quality of Two Groundnut (Arachis Hypogaea L.) Varieties. Agriprima, Journal of Applied Agricultural Sciences, 1 (1), 63-71.

Sriyanto, FB, Employee, AS, \& Sunaryo, S. (2019). The Effect of the Combination of Ga3 Hormones and Silica Fertilizer on the Quality and Quantity of Upright Bean Seeds (Phaseolus Vulgaris L.). Journal of Plant Production, 7 (8).

Sugari, D., \& Islami, T. (2019). Effect of Organic Fertilizer and Time of Weeding on Growth and Yield of 
Groundnut (Arachis Hypogaea L.). Journal of Crop Production, 6 (11).

Surya, BSLRB, Raja, LRBSL, Damanik, BSJ, \& Ginting, J. (2013). The Response of Groundnut Growth and Production to Tithonia Diversifolia Organic Ingredients and Sp-36 Fertilizer. Journal of Agroecotechnology, University of North Sumatra, 1 (3), 95345.

Taluta, HE, Rampe, HL, \& Rumondor, MJ (2017). Measurement of length and width of leaf stomata pores of several varieties of groundnut (Arachis Hypogaea L.). Mipa Journal, $6(2), 1-5$.

Ulhair, M., Nurhayati, N., \& Jumini, J. (2018). Effect of Bioboost and Guano Fertilizer on Growth and Yield of Groundnut (Arachis Hypogeae L.). Agricultural Student Scientific Journal, 3 (4), 53-64.

Wahyusi, KN, D Skip, R., Ragilia, RP, \& Kharisma, T. (2012). Groundnut Skin Charcoal Briquettes With Carbonization Process. Journal of Chemical Engineering, 6 (2), 70-73.

Yulianti, T. (2012). Exploring the Potential of Endophytes to Improve Sugarcane Plant Health to Support Increased Sugar Production. Journal of Perspectives, 11 (2), 113-123. 
Biosfer, 10 (1) (2020) 168-180

Noviani, Martha Lulus Lande, Zulkifli, Yulianty 